\title{
Frictional and hydrologic properties of a major splay fault system, Nankai subduction zone
}

\author{
Matt J. Ikari, ${ }^{1}$ Demian M. Saffer, ${ }^{1}$ and Chris Marone ${ }^{1}$ \\ Received 9 July 2009; revised 15 September 2009; accepted 28 September 2009; published 27 October 2009.
}

[1] We report on laboratory experiments examining the frictional and hydrologic properties of fault gouge and wall rock along a borehole transect that crosses a major out-of-sequence thrust splay fault within the Nankai accretionary complex. At $25 \mathrm{MPa}$ effective normal stress, the fault zone material is frictionally weak $(\mu \leq 0.44)$ and exhibits low permeability after shearing $(k<5.5 \times$ $10^{-20} \mathrm{~m}^{2}$ ). Fault zone samples are weaker and less permeable than the surrounding wall rocks, consistent with their slightly higher clay abundance. All samples exhibit velocity-strengthening frictional behavior over most of the experimental conditions we explored, consistent with aseismic slip at shallow depths. The fault and wall rock both exhibit prominent minima in the friction rate parameter $(a-b)$ for sliding velocities of $1-10 \mu \mathrm{m} / \mathrm{s}$ ( $\sim 0.1-1.0 \mathrm{~m} /$ day), comparable to rates for slow slip events. This suggests that the frictional properties of fault zone material play a central role in governing the mode of slip on subduction megathrusts. Citation: Ikari, M. J., D. M. Saffer, and C. Marone (2009), Frictional and hydrologic properties of a major splay fault system, Nankai subduction zone, Geophys. Res. Lett., 36, L20313, doi:10.1029/ 2009GL040009.

\section{Introduction}

[2] At subduction zones, sediments on the incoming oceanic plate are commonly underthrust beneath a forearc wedge and, at accretionary margins, the upper part of the sedimentary section is off-scraped forming an accretionary prism [Scholl et al., 1980; Underwood, 2007]. As a result, the plate boundary fault localizes within the sedimentary package, often within clay-rich strata [Deng and Underwood, 2001; Moore et al., 2001]. Within the accretionary prism, major out-of-sequence thrust (OOST) faults may splay off of the plate boundary, as in the Nankai subduction zone offshore Japan [Park et al., 2002; Moore et al., 2007] (Figure 1). At the Nankai margin, the extent of coseismic rupture for the 1944 Tonankai $\left(\mathrm{M}_{\mathrm{w}}=8.1\right)$ earthquake determined by tsunami and seismic waveform inversions (Figure 1b) suggests that significant coseismic slip occurred along a major splay fault, termed the "megasplay" [Sagiya and Thatcher, 1999; Park et al., 2000; Tanioka and Satake, 2001; Kikuchi et al., 2003]. This inference is consistent with theoretical studies that suggest rupture is likely to branch along such structures [Kame et al., 2003]. Interpretations of recent seismic reflection data indicate that

\footnotetext{
${ }^{1}$ Department of Geosciences, Pennsylvania State University, University Park, Pennsylvania, USA.
}

Copyright 2009 by the American Geophysical Union. 0094-8276/09/2009GL040009\$05.00 the megasplay is tectonically active [Park et al., 2002; Moore et al., 2007] and thus appears to also accommodate long term plate motion. Furthermore, recent work suggests that slow slip may occur along splay faults, both as very low frequency earthquakes [Ito and Obara, 2006] and in the form of postseismic relaxation [Sagiya and Thatcher, 1999].

[3] The frictional properties of fault rocks are a key control on fault shear strength, as well as rupture propagation and the nature of slip. The mode of fault slip, ranging from aseismic to slow events, tremor and earthquakes, has been correlated with the response of friction to slip velocity perturbations in laboratory experiments [e.g., Marone, 1998; Scholz, 2002]. Fault slip behavior is also closely related to fault-normal permeability. If permeability is sufficiently low, it can facilitate transient changes in strength via shear-enhanced compaction, thermal pressurization by frictional heating, or depressurization induced by dilatancy [e.g., Segall and Rice, 2006]. Previous work on analogs of natural fault gouge has shown that gouge mineralogy, and specifically the presence of clays, is a primary control on shear strength, frictional stability, and permeability [e.g., Morrow et al., 1992; Saffer and Marone, 2003; Crawford et al., 2008; Ikari et al., 2009]. Here, we report the results of shearing and permeability experiments conducted at conditions approximating those in-situ, on material retrieved from the Nankai megasplay fault during Integrated Ocean Drilling Program (IODP) Expedition 316.

\section{Geologic Setting: Nankai Accretionary Complex}

[4] The Nankai accretionary complex off the coast of SW Japan is formed by subduction of the Philippine Sea plate beneath the Eurasian plate (Figure 1). As noted above, a major feature of the accretionary complex is an outof-sequence splay fault bounding the seaward edge of the Kumano forearc basin, which branches from the main décollement $\sim 50-55 \mathrm{~km}$ landward of the deformation front and terminates near the seafloor $\sim 25 \mathrm{~km}$ from the deformation front [Moore et al., 2007, 2009] (Figure 1).

[5] We obtained a suite of samples collected during IODP Expedition 316, part of the Nankai Trough Seismogenic Zone Experiment (NanTroSEIZE) [Kimura et al., 2008]. These samples were retrieved from Site C0004 along a depth transect spanning the megasplay fault system, from 119-439 mbsf (meters below sea floor) (Figures 1 and 2). The hanging wall (lithologic Unit II, Figure 2) is mostly composed of upper to middle Pliocene hemipelagic mudstones, and extends from $78-258 \mathrm{mbsf}$. The main fault zone of the megasplay (lithologic Unit III) is a fault-bounded package between 258 and 308 mbsf defined by biostratigraphic age reversals [Kimura et al., 2008; Expedition 316 
A

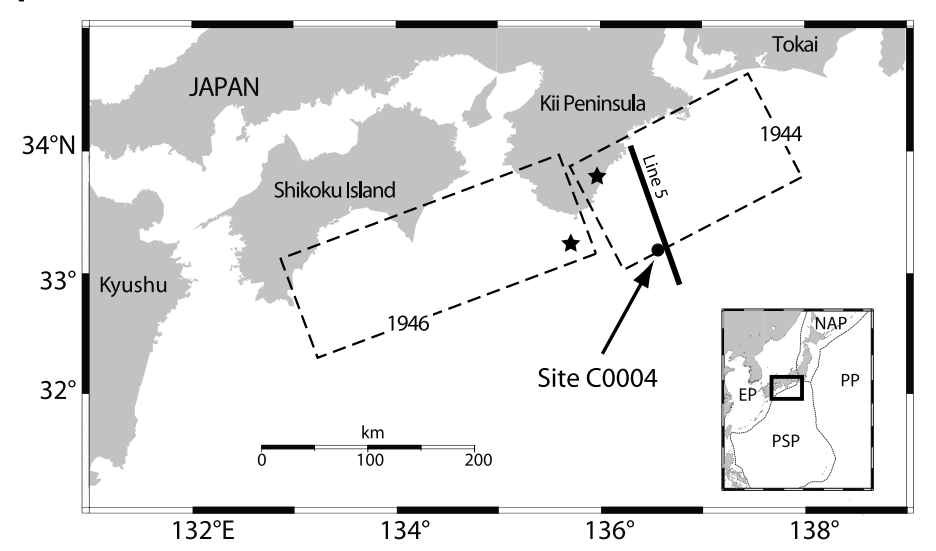

B Extent of 1944 Tonankai earthquake coseismic Extent of 1944 Tonankai earthquake coseismic rupture from tsunami waveform inversions* ${ }^{*}$ rupture from seismic waveform inversions ${ }^{* *}$

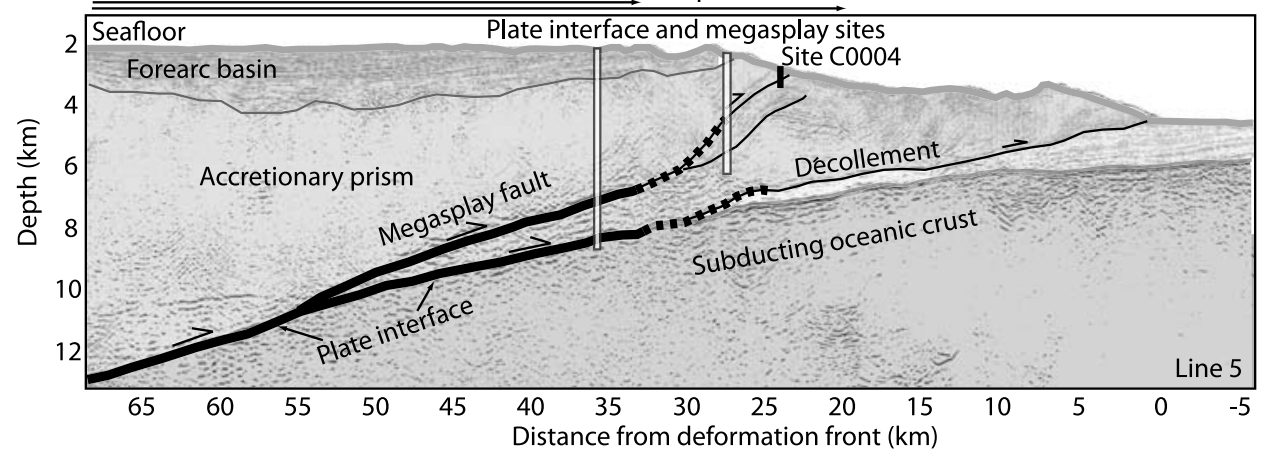

Figure 1. (a) Map of the Nankai area showing location of drill site C0004, as well as the rupture areas (dashed boxes) and epicenters (stars) of the 1944 Tonankai and 1946 Nankaido earthquakes (modified from Kimura et al. [2008]). (b) Profile of the megasplay along Line 5 in Figure 1a, showing drill site C0004, approximate location of our samples, and planned deeper drillsites. Also shown are estimates of the updip extent of coseismic slip inferred for the 1944 Tonankai earthquake [Tanioka and Satake, 2001; Kikuchi et al., 2003], (modified from Kimura et al. [2008]). The zone of coseismic slip is shown by heavy lines; dashed lines denote uncertainty based on difference between the two inversions.

Scientists, 2009]. It is composed of fractured and brecciated mid-Pliocene hemipelagic muds with minor interbedded volcanic ash. The footwall (lithologic Unit IV) is overridden slope apron sediment, consisting of lower Pleistocene finegrained hemipelagic claystones with some sand turbidite layers [Kimura et al., 2008; Expedition 316 Scientists, 2009]. Total clay mineral content generally ranges between $\sim 40 \%-70 \%$ within our study interval, plagioclase content ranges from $\sim 10 \%-40 \%$, and minor calcite is present throughout the section. The highest clay contents (and lowest plagioclase contents) occur within the fault zone (Figure 2) [Expedition 316 Scientists, 2009]. We conducted experiments on one sample from the hanging wall, four from the fault zone, and two from the footwall (Figure 2).

\section{Experimental Methods}

[6] We conducted experiments using a true-triaxial testing machine with servo-hydraulic control. Friction and permeability normal to the shear direction were measured under saturated and controlled pore pressure conditions in the double-direct shear geometry, in which two layers of gouge are sheared between two side forcing blocks and a central block, and fluids are introduced via porous frits at the sample faces (for a detailed description of the experimental configuration see Ikari et al. [2009]). The hanging wall sample and one footwall sample were tested as intact wafers trimmed from whole-round cores and sheared in a direction parallel to bedding (Figure 2). The four samples from the fault zone and a second sample from the footwall were obtained as brecciated mudstone. These samples were dried at $\sim 40^{\circ} \mathrm{C}$, disaggregated by hand, and sieved to a grain size of $<106 \mu \mathrm{m}$ to remove any remaining large mudstone aggregates, and to limit the effects of grain size and comminution of these aggregates on friction at low shear strains $(<\sim 5)$. Upon saturation and application of normal stress (prior to shearing), layer thickness of the disaggregated gouge was $\sim 1.5 \mathrm{~mm}$. The fragile nature of the intact wafers required the use of thicker samples (2.5 to $4 \mathrm{~mm}$ prior to shearing).

[7] In each experiment, shear was implemented as a displacement rate boundary condition $(11 \mu \mathrm{m} / \mathrm{s})$ at the gouge layer boundary. Effective normal stress was maintained at $25 \mathrm{MPa}$, and includes the combined effects of confining pressure $\left(\mathrm{P}_{\mathrm{c}}\right)$, externally applied normal load, and pore pressure $\left(\mathrm{P}_{\mathrm{p}}\right)$. During shear, $\mathrm{P}_{\mathrm{c}}$ was held constant at 6 $\mathrm{MPa}$, pore pressure at the upstream face of the sample $\left(\mathrm{Pp}_{\mathrm{a}}\right)$ was held constant at $5 \mathrm{MPa}$, and that at the downstream 


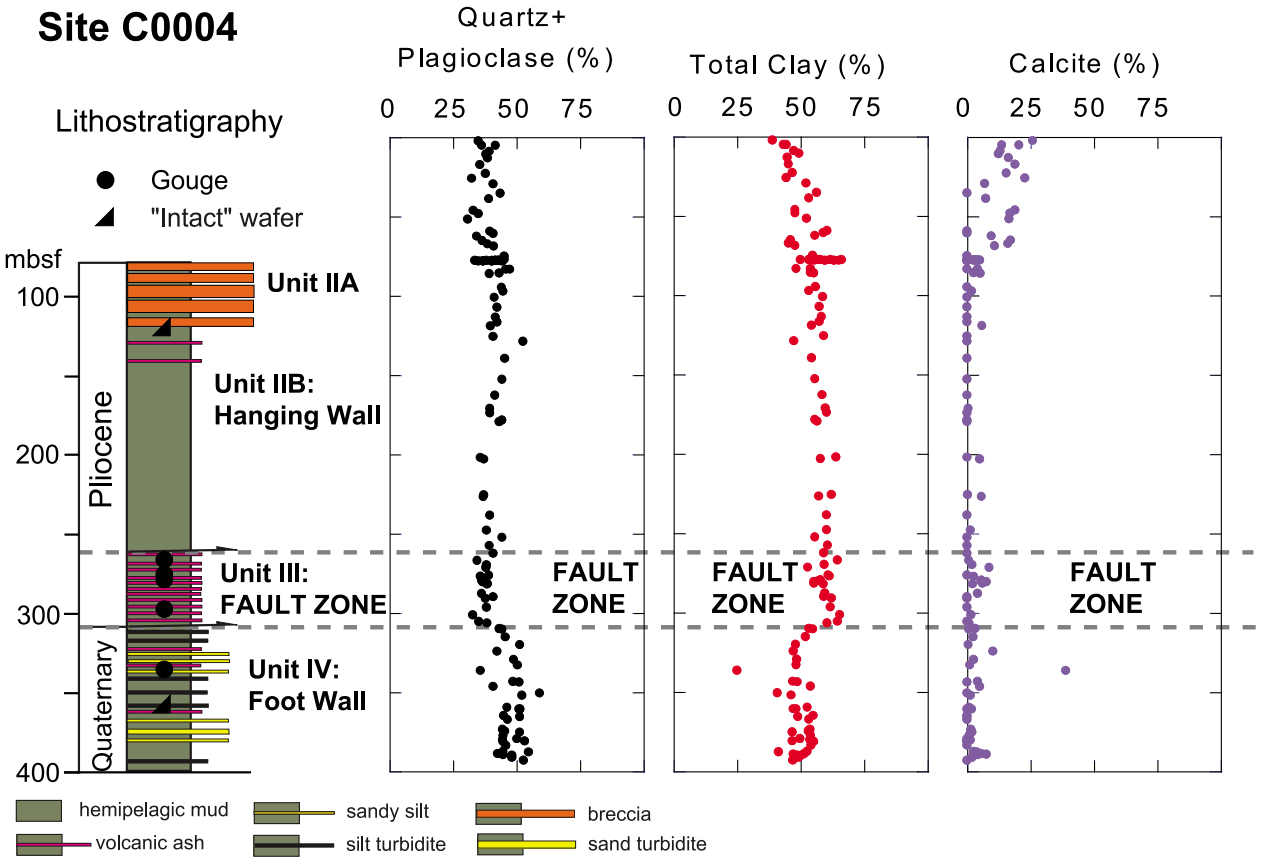

Figure 2. Summary of sample locations and lithostratigraphy (left column), and mineralogy data (right columns) at site C0004. The lithostratigraphy is modified from M. B. Underwood (unpublished data, 2009). Symbols show experimental sample locations superimposed on the column at the appropriate depth. We studied samples: C0004-15X-2, 27R-1, 29R-2, 30R-1, 34R-1, 42R-3, 47R-2, and 42R-3.

sample face of each layer $\left(\mathrm{Pp}_{\mathrm{b}}\right)$ was set to a no-flow (undrained) condition in order to monitor pore pressure [e.g., Ikari et al., 2009]. In order to simulate in-situ conditions, we used $3.5 \mathrm{wt} \% \mathrm{NaCl}$ brine as pore fluid. After attainment of steady-state shear stress (typically at shear strain of $\sim 5$ ), we measured friction constitutive properties using velocity-step tests that consisted of a factor of 3 jump in velocity in the range $0.03-100 \mu \mathrm{m} / \mathrm{s}$. After shearing, a constant pore pressure gradient was applied across the layer perpendicular to the shear direction, and the resulting steady-state flow rate was used to calculate the permeability (k) by Darcy's law.

[8] We measure the steady-state shear stress $(\tau)$ prior to the initiation of velocity steps. The coefficient of sliding friction $\mu$ is calculated by:

$$
\tau=\mu \sigma_{n}^{\prime}+c
$$

where $c$ is cohesion (assumed to be negligible), and $\sigma_{n}{ }^{\prime}$ is the effective normal stress, computed using the average of the pore pressures at the drained and undrained boundaries. We quantify frictional stability using the friction rate parameter $(a-b)$ :

$$
a-b=\frac{\Delta \mu_{s s}}{\ln \left(V / V_{o}\right)}
$$

where $\Delta \mu_{s s}$ is the change in the steady-state coefficient of friction for a change in sliding velocity from $V_{o}$ to $V$ [e.g., Marone, 1998]. Positive values of $(a-b)$ indicate velocitystrengthening behavior, whereas negative values indicate velocity-weakening, a necessary (though not sufficient) condition for stick-slip behavior associated with earthquake nucleation [Scholz, 2002]. We determined values of the friction rate parameter $(a-b)$ and other constitutive parameters using an inverse modeling technique with an iterative least-squares method, using Dieterich's [1979] constitutive law for friction coupled with an expression describing machine stiffness [Reinen and Weeks, 1993; Saffer and Marone, 2003; Ikari et al., 2009].

\section{Results}

[9] All of the samples we tested are frictionally weak, with a coefficient of friction $\mu<0.5$. The weakest samples are from within the fault zone $(0.37 \leq \mu \leq 0.44)$, and these have significantly lower strength than the surrounding wall rocks $(0.41 \leq \mu \leq 0.47)$ (Figure $3 a)$. Post-shear permeability $(k)$ for all of the samples is $\leq 7.0 \times 10^{-19} \mathrm{~m}^{2}$ (Figure $3 \mathrm{~b}$ ). Samples from within the fault zone are uniformly less permeable $\left(2.2 \times 10^{-20}<k<5.5 \times 10^{-20} \mathrm{~m}^{2}\right)$ than the surrounding wall rocks $\left(1.5 \times 10^{-19}<k<7.0 \times 10^{-19} \mathrm{~m}^{2}\right)$. The low overall values of friction and permeability are consistent with previous experimental studies of saturated clay-rich gouges [e.g., Crawford et al., 2008; Ikari et al., 2009].

[10] In contrast to the frictional strength and permeability values, the frictional velocity dependence $(a-b)$ is similar for the fault zone and wall rocks. With one exception (sample C0004D-42R-3, $335.42 \mathrm{mbsf}),(a-b)$ is uniformly positive, ranging from 0.0004-0.0069 (Figures 3c and 3d). For all of our samples, the lowest values of $(a-b)$, including the one observation of velocity-weakening, occur at slip velocities of $1-10 \mu \mathrm{m} / \mathrm{s}$. In comparing the intact 


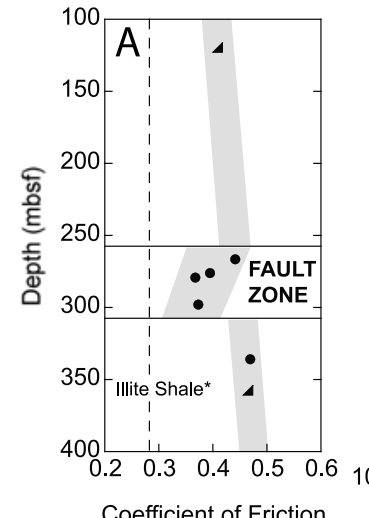

Coefficient of Friction

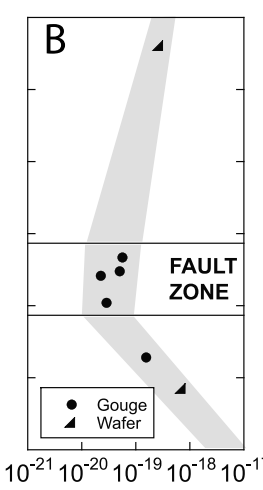

Permeability $\left(\mathrm{m}^{2}\right)$

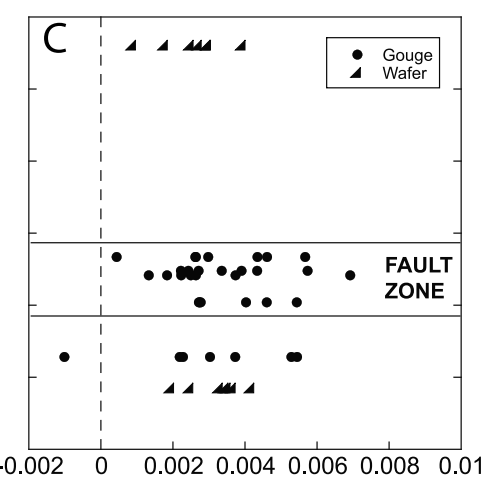

Friction Rate Parameter $a-b$

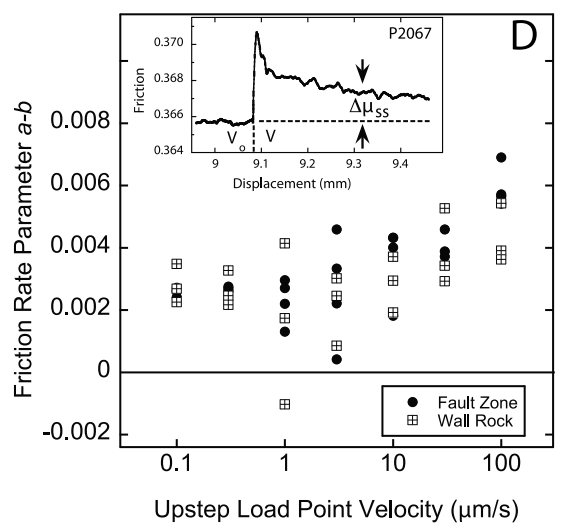

Figure 3. (a) Coefficient of friction $\mu$ as a function of depth. A reference line is shown for illite shale $(\mu=0.285)$ under similar experimental conditions [Ikari et al., 2009]; an envelope illustrating the range of the measurements is shown by gray shading. (b) Permeability $k$ as a function of depth. (c) Friction rate parameter $(a-b)$ as a function of depth. (d) $(a-b)$ as a function of up-step load point velocity. Inset shows data from a representative velocity step test from $0.1-0.3 \mu \mathrm{m} / \mathrm{s}$ (Sample C0004D-30R-1, experiment p2067), indicating velocity-strengthening frictional behavior.

footwall sample with the disaggregated and remolded footwall sample, we find that their frictional strength, velocitydependence, and permeability are similar (Figure 3 ).

\section{Implications for Fault Slip and Hydrologic Behavior}

[11] Although the samples we tested are lithologically similar to first-order (described as hemipelagic mudstones), material from within the fault zone is consistently weaker than the wall rocks. Samples from within the fault zone also exhibit both lower permeability than the wall rock samples, and low absolute values of permeability. These observations are consistent with slightly higher clay content in the fault zone $(\sim 55 \%$ vs. $\sim 40 \%)$, especially in comparison to the footwall [Deng and Underwood, 2001]. Low permeability may facilitate both high ambient pore pressures within the fault zone and transient strength changes during slip. The similarity of frictional strength and permeability for intact wafers and disaggregated gouge suggests that for these relatively shallow samples, lithification and fabric are poorly developed and/or have little effect on mechanical and hydrologic properties.

[12] Frictional velocity dependence is almost always positive and does not vary significantly between samples or as a function of position across the fault zone (Figures $3 \mathrm{c}$ and $3 \mathrm{~d}$ ). This is consistent with several recent studies showing that clay-rich gouges are generally velocitystrengthening [e.g., Morrow et al., 1992; Saffer and Marone, 2003; Ikari et al., 2009]. The slight differences in mineralogy between the fault zone and wall rocks that appear to influence frictional strength and permeability do not affect the frictional stability, consistent with previous work showing that $(a-b)$ is less sensitive to changes in clay mineral content than is frictional strength [Ikari et al., 2007].

[13] The overall velocity-strengthening behavior of the fault zone indicates that seismic slip will not nucleate along the megasplay at these shallow depths, and if coseismic slip propagates from a nucleation zone deeper on the fault, it would need to overcome the stabilizing properties of the shallow fault zone for rupture to reach the seafloor. Due to low permeability, this effect would be magnified by dilation-induced depressurization in low-permeability gouge, which would lead to strengthening and further stabilize slip [e.g., Segall and Rice, 2006]. Although coseismic slip may not reach the seabed, other types of transient slip phenomena may propagate along faults with near velocity-neutral frictional behavior [Rubin, 2008]. Our work indicates that seismic slip on deeper parts of the megasplay may ultimately reach the seafloor in the form of postseismic relaxation (earthquake afterslip) [Marone et al., 1991; Perfettini and Ampuero, 2008], slow slip events, or low frequency earthquakes [e.g., Ito and Obara, 2006]. This is consistent with recent studies documenting reverse faulting focal mechanisms for very low frequency earthquakes in the accretionary wedge that likely initiated on out-of-sequence thrusts [Ito and Obara, 2006]. Postseismic relaxation has been documented in the region of great Nankai earthquakes [Thatcher, 1984] and much of it likely occurs along splay faults [Ito and Obara, 2006].

[14] Notably, the lowest values of $(a-b)$ in our experiments occur for sliding velocities of $1-10 \mu \mathrm{m} / \mathrm{s}$ ( $\sim 0.1-1 \mathrm{~m} /$ day) (Figure $3 \mathrm{~d})$. This is slightly higher than the observed dvelocities for slow slip events at the Nankai margin and earthquake afterslip in northeast Japan, reported at $1.1-4.3 \times 10^{-8} \mathrm{~m} / \mathrm{s}(0.011-0.043 \mu \mathrm{m} / \mathrm{s})$ [Ide et al., 2007], but approximately matches the range of estimated slip velocity of $1.5-5.0 \times 10^{-7} \mathrm{~m} / \mathrm{s}(0.15-0.5 \mu \mathrm{m} / \mathrm{s})$ for slow earthquakes on the San Andreas Fault in California [Linde et al., 1996; Ide et al., 2007]. Based on our experimental data, the frictional stability of the fault zone should increase at slip velocities $>\sim 10 \mu \mathrm{m} / \mathrm{s}$, which is a condition that favors slow slip by arresting nucleation of a dynamic rupture [Rubin, 2008].

\section{Conclusions}

[15] Shear strength and permeability in the megasplay are low throughout the depth range examined in this study, consistent with its clay-rich lithology. Friction coefficient and permeability of the fault zone are both lower than that of the hanging wall and footwall, which may be related to 
slightly higher clay content in the fault zone. All samples exhibit stable frictional behavior, also consistent with clayrich lithology, but $(a-b)$ values are relatively insensitive to these mineralogical variations. The velocity-strengthening behavior of the fault zone suggests that seismic rupture is unlikely to reach the seafloor. However, velocity-strengthening friction and the observed consistent minima in $(a-b)$ at sliding velocities of $1-10 \mu \mathrm{m} / \mathrm{s}$ are favorable for earthquake afterslip and interseismic slow slip events, which may be common at shallow depths along the megasplay.

[16] Acknowledgments. This work was supported by NSF awards EAR-0746192, EAR-0752114, and OCE-0648331 to C.M. and D.M.S. We thank Mike Underwood for discussions about stratigraphy, and Greg Moore and an anonymous reviewer for constructive comments that improved this manuscript.

\section{References}

Crawford, B. R., D. R. Faulkner, and E. H. Rutter (2008), Strength, porosity, and permeability development during hydrostatic and shear loading of synthetic quartz-clay fault gouge, J. Geophys. Res., 113, B03207, doi:10.1029/2006JB004634

Deng, X., and M. B. Underwood (2001), Abundance of smectite and the location of a plate-boundary fault, Barbados accretionary prism, Geol. Soc. Am. Bull., 113, 495-507, doi:10.1130/0016-7606(2001)113 $<0495$ :AOSATL $>2.0$.CO;2.

Dieterich, J. H. (1979), Modeling of rock friction: 1. Experimental results and constitutive equations, J. Geophys. Res., 84, 2161-2168, doi:10.1029/JB084iB05p02161.

Expedition 316 Scientists (2009), Expedition 316 Site C0004, Proc. IODP, 314/315/316, doi:10.2204/iodp.proc.314315316.133.2009.

Ide, S., G. C. Beroza, D. R. Shelly, and T. Uchide (2007), A scaling law for slow earthquakes, Nature, 447, 76-79, doi:10.1038/nature05780.

Ikari, M. J., D. M. Saffer, and C. Marone (2007), Effect of hydration state on the frictional properties of montmorillonite-based fault gouge, J. Geophys. Res., 112, B06423, doi:10.1029/2006JB004748.

Ikari, M. J., D. M. Saffer, and C. Marone (2009), Frictional and hydrologic properties of clay-rich fault gouge, J. Geophys. Res., 114, B05409, doi:10.1029/2008JB006089.

Ito, Y., and K. Obara (2006), Dynamic deformation of the accretionary prism excites very low frequency earthquakes, Geophys. Res. Lett., 33, L02311, doi:10.1029/2005GL025270.

Kame, N., J. R. Rice, and R. Dmowska (2003), Effects of pre-stress state and rupture velocity on dynamic fault branching, J. Geophys. Res., 108(B5), 2265, doi:10.1029/2002JB002189.

Kikuchi, M., M. Nakamura, and K. Yoshikawa (2003), Source rupture processes of the 1944 Tonankai earthquake and the 1945 Mikawa earthquake derived from low-gain seismograms, Earth Planets Space, 55, 159-172.

Kimura, G., E. J. Screaton, D. Curewitz, and Expedition 316 Scientists (2008), NanTroSEIZE Stage 1A: NanTroSEIZE shallow megasplay and frontal thrusts, IODP Prelim. Rep. 316, Ocean Drill. Progam, College Staton, Tex.

Linde, A. T., M. T. Gladwin, M. J. S. Johnston, R. L. Gwyther, and R. G. Bilham (1996), A slow earthquake sequence on the San Andreas fault, Nature, 383, 65-68, doi:10.1038/383065a0.

Marone, C. (1998), Laboratory-derived friction laws and their application to seismic faulting, Annu. Rev. Earth Planet. Sci., 26, 643-696, doi:10.1146/annurev.earth.26.1.643.

Marone, C. J., C. H. Scholz, and R. Bilham (1991), On the mechanics of earthquake afterslip, J. Geophys. Res., 96, 8441-8452, doi:10.1029/ 91JB00275.
Moore, G. F., et al. (2001), New insights into deformation and fluid flow processes in the Nankai Trough accretionary prism: Results of Ocean Drilling Program Leg 190, Geochem. Geophys. Geosyst., 2(10), 1058 , doi:10.1029/2001GC000166.

Moore, G. F., N. L. Bangs, A. Taira, S. Kuramoto, E. Pangborn, and H. J. Tobin (2007), Three-dimensional splay fault geometry and implications for tsunami generation, Science, 318, 1128-1131, doi:10.1126/ science. 1147195

Moore, G. F., et al. (2009), Structural and seismic framework of the NanTroSEIZE Stage 1 transect, Proc. IODP, 314/315/316, doi:10.2204/ iodp.proc.314315316.102.2009.

Morrow, C., B. Radney, and J. Byerlee (1992), Frictional strength and the effective pressure law of montmorillonite and illite clays, in Fault Mechanics and Transport Properties of Rocks, Int. Geophys. Ser, vol. 51, edited by B. Evans and T.-F. Wong, pp. 69-88, Academic, London.

Park, J.-O., T. Tsuru, S. Kodaira, A. Nakanishi, S. Miura, Y. Kaneda, and Y. Kono (2000), Out-of-sequence thrust faults developed in the coseismic slip zone of the 1946 Nankai earthquake $(\mathrm{Mw}=8.2)$ off Shikoku, southwest Japan, Geophys. Res. Lett., 27, 1033-1036, doi:10.1029/ 1999GL008443.

Park, J.-O., T. Tsuru, S. Kodaira, P. R. Cummins, and Y. Kaneda (2002), Splay fault branching along the Nankai subduction zone, Science, 297, 1157-1160, doi:10.1126/science.1074111.

Perfettini, H., and J.-P. Ampuero (2008), Dynamics of a velocity strengthening fault region: Implications for slow earthquakes and postseismic slip, J. Geophys. Res., 113, B09411, doi:10.1029/2007JB005398.

Reinen, L. A., and J. D. Weeks (1993), Determination of rock friction constitutive parameters using an iterative least-squares inversion method, J. Geophys. Res., 98, 15,937-15,950, doi:10.1029/93JB00780.

Rubin, A. M. (2008), Episodic slow slip events and rate-and-state friction, J. Geophys. Res., 113, B11414, doi:10.1029/2008JB005642.

Saffer, D. M., and C. Marone (2003), Comparison of smectite- and illiterich gouge frictional properties: Application to the updip limit of the seismogenic zone along subduction megathrusts, Earth Planet. Sci. Lett., 215, 219-235, doi:10.1016/S0012-821X(03)00424-2.

Sagiya, T., and W. Thatcher (1999), Coseismic slip resolution along a plate boundary megathrust: The Nankai Trough, southwest Japan, J. Geophys. Res., 104, 1111-1129, doi:10.1029/98JB02644.

Scholl, D. W., R. von Huene, T. L. Vallier, and D. G. Howell (1980), Sedimentary masses and concepts about tectonic processes at underthrust ocean margins, Geology, 8, 564-568, doi:10.1130/0091-7613(1980)8 $<564$ :SMACAT $>2.0 . \mathrm{CO} ; 2$.

Scholz, C. H. (2002), The Mechanics of Earthquakes and Faulting, 2nd ed., Cambridge Univ. Press, New York.

Segall, P., and J. R. Rice (2006), Does shear heating of pore fluid contribute to earthquake nucleation?, J. Geophys. Res., 111, B09316, doi:10.1029/ 2005JB004129.

Tanioka, Y., and K. Satake (2001), Detailed coseismic slip distribution of the 1944 Tonankai earthquake estimated from tsunami waveforms, Geophys. Res. Lett., 28, 1075-1078, doi:10.1029/2000GL012284.

Thatcher, W. (1984), The earthquake deformation cycle at the Nankai Trough, southwest Japan, J. Geophys. Res., 89, 3087-3101, doi:10.1029/JB089iB05p03087.

Underwood, M. B. (2007), Sediment inputs to subduction zones: Why lithostratigraphy and clay mineralogy matter, in The Seismogenic Zone of Subduction Thrust Faults, edited by T. H. Dixon and J. C. Moore, pp. 42-85, Columbia Univ. Press, New York.

M. J. Ikari, C. Marone, and D. M. Saffer, Department of Geosciences, Pennsylvania State University, 536 Deike Bldg., University Park, PA 16802, USA. (mikari@geosc.psu.edu) 